Article

\title{
Hydrogeology of Reclaimed Floodplain in A Permafrost Area, Yakutsk, Russia
}

\author{
Nadezhda Pavlova ${ }^{1, *(\mathbb{D})}$, Vasily Ogonerov ${ }^{1}$, Marina Danzanova ${ }^{1}$ and Vladimir Popov ${ }^{2}$ \\ 1 Melnikov Permafrost Institute of the Siberian Branch of Russian Academy of Sciences, Merzlotnaya St., 36, \\ 677010 Yakutsk, Russia; vasvas392@yandex.ru (V.O.); dmv_1585@mail.ru (M.D.) \\ 2 Ammosov North-Eastern Federal University in Yakutsk, Belinskogo St., 58, 677000 Yakutsk, Russia; \\ pvf_grf@rambler.ru \\ * Correspondence: na-pavlova@yandex.ru
}

Received: 9 March 2020; Accepted: 19 May 2020; Published: 20 May 2020

check for updates

\begin{abstract}
A study was performed to evaluate the current permafrost and groundwater conditions in the reclaimed floodplain of the Lena, one of the largest rivers in the permafrost zone. Data from ongoing hydrogeological monitoring were compared with earlier observations conducted during the reclamation process. The results demonstrate that the placement of dredged fill led to the development of suprapermafrost thaw zones (taliks). The anthropogenic taliks vary in thickness from 10 to $15 \mathrm{~m}$ in areas of buried bars to $20 \mathrm{~m}$ or more in the former locations of oxbow lakes. There is similarity in seasonal groundwater fluctuation patterns and response to river stage variations across the study area suggesting that a continuous aquifer connected to surface water. The connection with the river is most evident during the spring flood period. Two mechanisms of ground saturation are identified during this time. One is lateral seepage flow from the Lena River into the fill mass. The zone of its influence is limited to $150-170 \mathrm{~m}$ from the stream. The second is hydraulic pressure transmission from the river through the subchannel flow connected with the anthropogenic suprapermafrost aquifer. Its influence extends across the entire fill area. Continuous water movement at the base of the fill prevents permafrost aggradation from below. The study results should be taken into account when developing and implementing design and construction standards for engineering structures in the reclaimed floodplains of the permafrost zone.
\end{abstract}

Keywords: floodplain; hydraulic fill; water-bearing talik; permafrost; groundwater; monitoring; hydraulic connection; flooding

\section{Introduction}

Urbanization processes are inevitably accompanied by the expansion of residential and commercial areas. Where suitable land for housing is in short supply, it is an accepted practice to use shallow coastal areas and river floodplains previously deemed unsuitable. The most common method of land reclamation in seasonally flooded areas is hydraulic filling. Major hydraulic fill projects have been undertaken in the Netherlands, Denmark, Dubai, China, Singapore, and Japan $[1,2]$. In Russia, several neighborhoods in St. Petersburg were built on the land reclaimed by hydraulic filling; smaller-scale projects were also undertaken in Omsk, Nizhny Novgorod, Arkhangelsk, Perm, and Kazan [3-8].

The use of hydraulic fills frequently poses problems associated with saturated foundation materials. These include soil liquefaction during seismic events, chemical leaching of fill sand due to interaction with groundwater, and heterogeneous micro-layered structure of the fill mass which may result in reduced soil bearing capacity and differential settlement $[9,10]$. 
Consequently, investigating the hydrodynamic regime of an anthropogenic aquifer and its interaction with natural hydrogeological conditions is an integral part of the geotechnical assessment of reclamation areas [11]. This is particularly important for permafrost regions because hydrogeology may become a decisive argument when selecting a foundation design approach.

In permafrost regions, the practice of hydraulic filling is generally used for infrastructure projects such as roads, airports, pipelines, dams, harbors, and oil and gas facilities [12-16]. The design and construction approach commonly used for these projects is to maintain the fill soils and underlying ground in a frozen state during the service life of the structure $[17,18]$.

This approach, termed Principe I in the Russian building codes, was adopted initially for housing developments on reclaimed land in Yakutsk, the largest city in the continuous permafrost zone $[19,20]$. However, investigations conducted in 2013-2019 have shown that the ground temperatures are presently above $0{ }^{\circ} \mathrm{C}$ down to depths of $10 \mathrm{~m}$ or more over much of the new districts and the buildings are supported by unfrozen foundations [21-23]. In other words, the foundation soils are used in the thawed or thawing state as stipulated by Principle II in the construction guidelines [17,18]. The deep Lena River flowing nearby and taliks (unfrozen zones) present beneath the river are thought to be responsible, among other things, for the persistence of taliks in the buried floodplain area, as well as for the hydrothermal regime in the upper part of the man-made ground. Understanding how the current thermal and hydrogeological conditions have evolved over recent years, as well as assessing the influence of groundwater and surface water on the subgrade temperature distributions are important for maintaining the safety of existing buildings and for strategic planning of future development in floodplain environments.

\section{Problem Statement}

Yakutsk is one of the oldest cities in eastern Siberia. It is situated within a valley of the middle Lena River in central Yakutia (Figure 1). Most of the city is located on a low river terrace, 5 to $10 \mathrm{~km}$ wide, above the current floodplain. Relief of the terrace is generally low with an elevation range of 94 to $102 \mathrm{~m}$ above sea level [24]. Permafrost in the Yakutsk area is continuous in extent and varies in thickness from 250 to $422 \mathrm{~m}$ [25]. Open taliks penetrating through the permafrost have been identified only below Beloe Lake with an area of $0.8 \mathrm{~km}^{2}$, as well as in the Tabaga and Kangalas Point areas where the Lena River channel intersects tectonic faults.

The material to depths of 2-4 m consists of sandy and clayey silts, often laden with mud and peat. These deposits are underlain by fine to very fine sands with occasional peat and ice layers. Below 4-8 $\mathrm{m}$, there are medium to coarse sands with inclusions of gravel in the lower part. The total thickness of the alluvial deposits is $17-25 \mathrm{~m}$. The alluvium is underlain by Jurassic terrigenous material. Seasonal soil thaw depths vary from 0.5 to $4.0 \mathrm{~m}$ [26]. Suprapermafrost water occurs above the confining permafrost from June until December when the active layer freezes back completely [27]. Closed taliks, up to $20 \mathrm{~m}$ thick, are present below small lakes which predominantly occur in the rear part of the terrace. Talik contours are similar in plan-view to the lake shapes. Low relief and the presence of low-permeability silts near the surface, along with impervious frozen ground which forms beneath the roads, impede surface and subsurface drainage [28]. This results in waterlogging and frost action which pose risk to the stability of buildings and infrastructure.

The growth of Yakutsk's population from the early 1970s and the shortage of areas with suitable ground conditions caused pressure for new land. One solution to the problem involved the creation of construction sites for two housing projects by hydraulic filling on the floodplain of the Lena River $[15,19]$. It should be noted that these projects are the first, and so far the only, such undertakings implemented in the permafrost region.

The floodplain was reclaimed for two housing projects, District 202 and District $203[15,20]$. For District 202, alluvial sands were dredged during the summers of 1979-1982 in a secondary channel of the Lena River, after which planned development on the new site was begun. Dredged fill for the District 203 project was created in the late 1980s-early 1990s in an adjacent upstream area. Construction 
activities on this site started in 2013. The total area of the reclaimed land is $0.67 \mathrm{~km}^{2}$, and the thickness of the fill mass ranges from 4 to $15 \mathrm{~m}$. The surface of the fill ground has elevations of $97-98 \mathrm{~m}$ to protect against flooding.

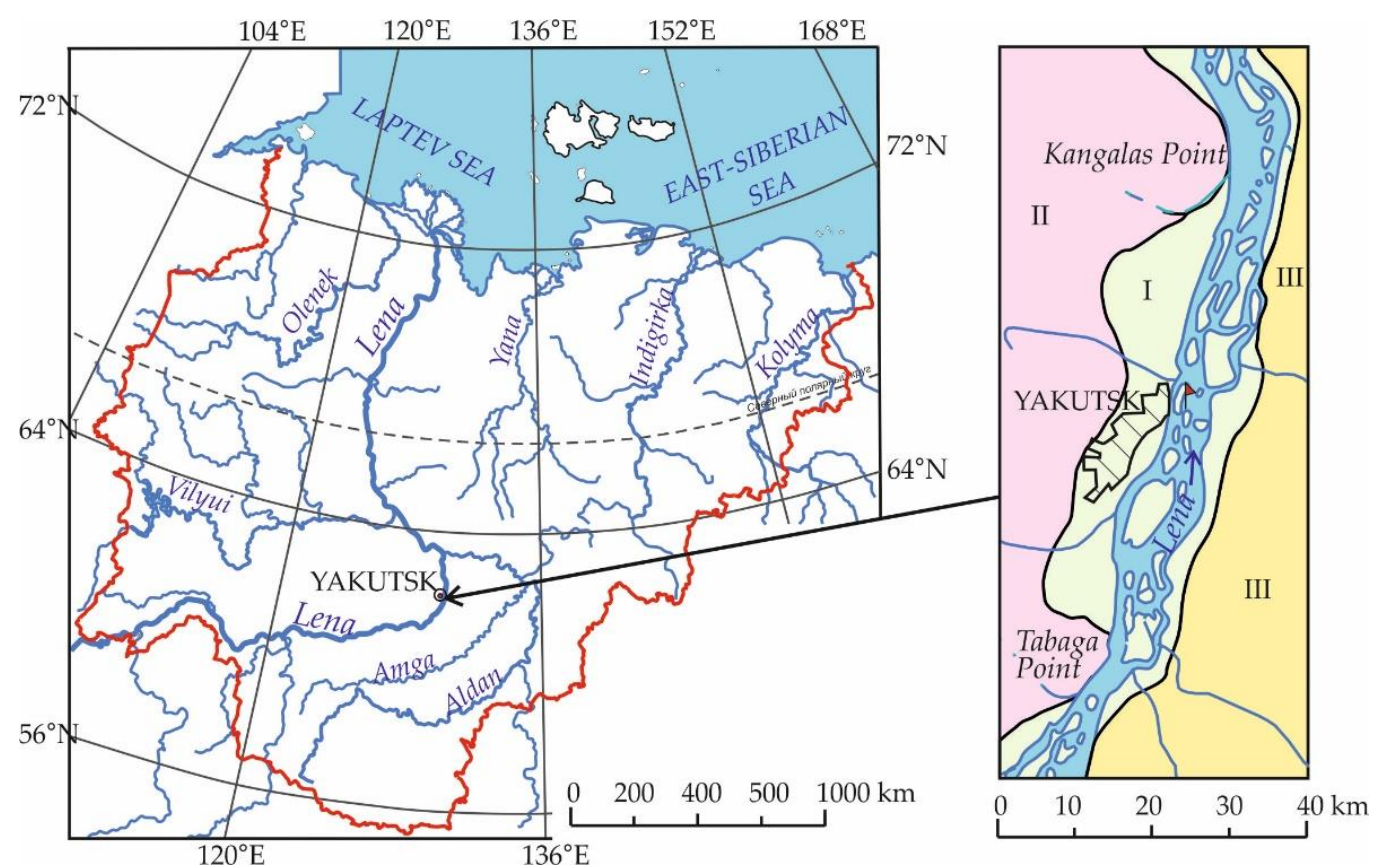

Figure 1. Study area on the Yakutia map and on the morphological scheme: I-Valley of the Lena River; II-Prilenskoe Plateau; III—the Lena-Amga plain; flag—hydrological gauge near Yakutsk.

As District 202 was the first hydraulic fill project undertaken in an area with difficult permafrost and hydrogeological conditions, a comprehensive research program consisting of field observations, laboratory experiments and full-scale testing was carried out prior to construction [15]. These studies provided a better understanding of the factors that control the mechanical behavior of fill sands and natural soils. A two-stage fill placement technology, as well as several foundation designs, was tested. Based on the results obtained, the passive design and construction approach was chosen which intended to maintain the foundation materials in a frozen state.

The first detailed analyses of the hydrogeology and groundwater regime in reclaimed areas with permafrost were presented by Roman et al. [15,20]. Based on the data from hydrogeological observations conducted in 1992-1994 in the District 202 area in Yakutsk, they examined the development of anthropogenic taliks during the dredging and filling period and identified three major factors influencing the groundwater dynamics during construction on the new site. During the spring flood period, the Lena River was found to play a dominant role in groundwater recharge as indicated by synchronous water level rises in the river and observation boreholes. In summer, the water table rise in the completed fill was primarily caused by hydraulic filling operations in a neighboring area. In autumn and winter, leaks from water mains were not uncommon, causing high groundwater levels. The latter two factors contributed to ground temperature warming. When hydraulic filling operations were completed, the fill soils began cooling although their temperatures remained above $0{ }^{\circ} \mathrm{C}$. Numerical analyses performed by various authors predicted that the redeposited sands and underlying natural ground would freeze back 6-150 years after construction [15]. Similar patterns of groundwater and temperature dynamics were assumed for the adjacent, District 203 project site located up the river. In 1996, temperature and groundwater observations were discontinued. Ground temperature measurements in District 202 were resumed in 2009 and continued until 2015. They showed that the depth of seasonal freezing was about $4.5 \mathrm{~m}$. Suprapermafrost subaerial taliks extended to a depth of 10 
$\mathrm{m}$ or more, and only some thin layers of newly formed permafrost with mean annual temperatures of -0.3 to $-0.6^{\circ} \mathrm{C}$ occurred locally at a depth of $5 \mathrm{~m}[23]$.

\section{Methods}

The study reported here describes the ground and groundwater conditions that have developed in the District 203 area. Geotechnical data collected by several geotechnical engineering companies and research institutes in 2013-2019, i.e., over 25 years after the placement of dredged fill, provided baseline information for evaluating the current status of the fill and the spatial extent of groundwater. We also used data from a hydrogeological monitoring network which was established in the study area in 2014-2015. It consisted of four clusters of paired hydrogeological and thermal boreholes. Two clusters were installed in locations of relict sub-lake taliks and the other two were in areas of buried sandbars. During drilling, soil cores were collected from the aeration zone at a regular interval (every one meter) for gravimetric moisture content determination. The hydrogeological boreholes were cased to depths of 15-22 m and screened with mesh over the intervals of groundwater occurrence. Until 2016, groundwater levels were measured once a month, with more frequent measurements during the spring flood period. Groundwater sampling for hydrogeochemistry was made once a month during the first year of observation and every four months afterward. Samples, $0.5 \mathrm{~L}$ in volume, were collected in chemically pure polyethylene bottles cleaned with distilled water and rinsed several times with sample water before collection. Water $\mathrm{pH}$ and temperature were measured at the sampling site.

The temperature measurement boreholes were cased with watertight polyethylene tubing. Ground temperatures were recorded monthly with portable cables, having sensors at $0.5 \mathrm{~m}$ intervals from the surface to a depth of $5 \mathrm{~m}$ and at a 1-m spacing to a depth of $10 \mathrm{~m}$. The data obtained from 2014 to 2016 characterize the groundwater regime and ground temperatures before the completion of buildings and underground utilities. Three borehole clusters were later destroyed during construction.

In 2019, groundwater observations were made in five boreholes drilled near the completed buildings. One borehole (No. 10) was equipped with a data logger for automatic recording of water level and temperature. Readings were taken once daily from May to August 2019.

Stream level records from the Yakutsk gauging station available online at the Russian River-Basin Water Resources and Management Information System were used to determine groundwater interaction with the Lena River. The station is located across the main channel of the Lena River.

River level data from the gaging station and groundwater level data from borehole No 10 were used to determine the hydraulic diffusivity of the aquifer [29] (pp. 130-132). This parameter characterizes the speed of hydrodynamic pulse propagation in the aquifer. Then, the response of groundwater level to river level rise was estimated for different probabilities. The classical head equation was used:

$$
S=s^{0} \operatorname{erfc} \frac{r}{2 \sqrt{a t}}
$$

where S-groundwater level at a given point, $\mathrm{m} ; \mathrm{r}$ - distance to the river, $\mathrm{m} ; \mathrm{s}^{0}$ —instantaneous rise in river level, $\mathrm{m}$; a-hydraulic diffusivity, $\mathrm{m}^{2} /$ day; $\mathrm{t}$-time since perturbation in the river (days).

Chemical characterization of the waters of the Lena River and underlying aquifer was based on the data from geotechnical reports and our own hydrochemical investigations. Analysis of the water samples was performed at the Melnikov Permafrost Institute using titration and capillary electrophoresis methods.

\section{Natural and Modified Environmental Characteristics of the Floodplain Area}

The reclaimed land in Yakutsk is bounded by a riser of the Lena River's first terrace on the west, a dyke on the north, and a side channel of the Lena River (named locally the City Canal) on the east. The Lena River is one of the largest lowland rivers in the world. Its valley between Tabaga and Kangalas Points is 5 to $10 \mathrm{~km}$ wide. The mean annual discharge near Yakutsk is $7070 \mathrm{~m}^{3} / \mathrm{s}$ [30,31]. The Lena River has a hydrologic regime of East-Siberian type, with its annual hydrograph dominated by spring 
peaks with a rapid rise in water level and secondary peaks in the summer and autumn. Groundwater contributes a few percent of river flow [31]. Freeze-up occurs in October. Water elevations are 81.7 to $83.5 \mathrm{~m}$ during the winter low-flow period (March-April). Water levels rise by 7 to $11 \mathrm{~m}$ during the spring high flow period, producing flooding of the wide floodplain. The highest levels near Yakutsk occur from ice jams when the $5 \%$ probability levels are $94.7 \mathrm{~m}$ and the long-term mean discharge is $36,200 \mathrm{~m}^{3} / \mathrm{s}$ [31]. The hydrograph is characterized by one to four peaks in the summer associated with rain events and thawing of the active layer of permafrost in the river basin. In some years, the extreme levels in June-July may exceed those in the spring (Table 1). Water temperatures vary with seasonal flow changes, from 0 to $1{ }^{\circ} \mathrm{C}$ during the spring flood period to about $10-12{ }^{\circ} \mathrm{C}$ and $15-17^{\circ} \mathrm{C}$ in June and July, respectively [32].

Table 1. Lena River water levels and summer precipitation in the Yakutsk area for 1992-1995 and 2014-2019.

\begin{tabular}{|c|c|c|c|c|c|c|c|c|c|}
\hline \multirow{3}{*}{ 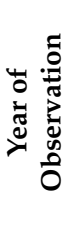 } & \multirow{3}{*}{ 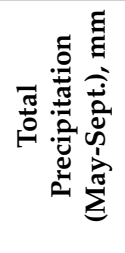 } & \multirow{3}{*}{ 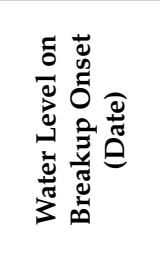 } & \multirow{3}{*}{ 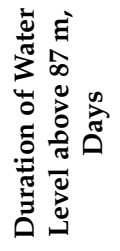 } & \multicolumn{6}{|c|}{ Seasonal Extremes of Water Level } \\
\hline & & & & \multicolumn{2}{|c|}{$\begin{array}{c}\text { Spring } \\
\text { (Mar.-May) }\end{array}$} & \multicolumn{2}{|c|}{$\begin{array}{c}\text { Summer } \\
\text { (Jun-Aug.) }\end{array}$} & \multicolumn{2}{|c|}{$\begin{array}{c}\text { Autumn } \\
\text { (Sept.-Nov.) }\end{array}$} \\
\hline & & & & Max & Min & Max & Min & Max & Min \\
\hline 1992 & 104 & $84.2(17.05)$ & 73 & 92.1 & 82.0 & 88.4 & 84.9 & 87.4 & 84.0 \\
\hline 1993 & 207 & 87.1 (22.05) & 127 & 90.1 & 83.0 & 89.7 & 84.3 & 87.6 & 85.0 \\
\hline 1994 & 199 & $89.1(22.05)$ & 60 & 90.5 & 82.0 & 91.6 & 84.1 & 87.3 & 84.0 \\
\hline 1995 & 110 & $86.7(24.05)$ & 150 & 91.6 & 83.0 & 91.2 & 84.4 & 85.7 & 84.0 \\
\hline 2014 & 170 & $88.5(8.05)$ & 36 & 89.5 & 81.9 & 88.3 & 84.08 & 88.0 & 82.9 \\
\hline 2015 & 125 & 89.3 (12.05) & 61 & 91.6 & 81.9 & 89.6 & 83.7 & 85,3 & 83.1 \\
\hline 2016 & 164 & $86.3(15.05)$ & 64 & 88.9 & 81.7 & 90.6 & 85.4 & 86.2 & 82.5 \\
\hline 2017 & 153 & $88.6(17.05)$ & 70 & 90.4 & 81.7 & 90.4 & 84.4 & 88.1 & 82.6 \\
\hline 2018 & 154 & $89.9(14.05)$ & 77 & 92.1 & 82.2 & 90.6 & 86.2 & 86.7 & 83.2 \\
\hline 2019 & 140 & $85.6(15.05)$ & 46 & 89.9 & 82.1 & 89.5 & 82.8 & 84.7 & 82.6 \\
\hline
\end{tabular}

Near Yakutsk, the Lena River has a multiple-channel pattern with numerous islands ranging from 0.5 to $10 \mathrm{~km}$ in length. The channels are subject to shifting in various directions $[33,34]$. The City Canal, for example, was a primary navigable channel in the early 20th century [33]. In the 1940s-early 1950s, the dynamic axis of the river flow shifted toward the right bank [34]. In subsequent years, the City Canal gradually shallowed to become a secondary channel within the floodplain (Figure 2).

The chemistry of the Lena River exhibits seasonal variations reflecting the inputs from different sources. In the spring and summer when snowmelt and rainfall are dominant contributors to streamflow, the water is of the sodium calcium or magnesium calcium chloride-bicarbonate type, with dissolved-solids contents ranging from 70 to $100 \mathrm{mg} / \mathrm{L}$. The concentration of dissolved solids increases to $170-180 \mathrm{mg} / \mathrm{L}$ by the end of the summer [35]. The $\mathrm{pH}$ values of the water are between 6.4 and 7.7 . During the winter when the flow is maintained by groundwater, dissolved-solids contents are 500-700 $\mathrm{mg} / \mathrm{L}$ in the main channel and up to $800 \mathrm{mg} / \mathrm{L}$ in the side channels near Yakutsk. The water type becomes calcium sodium chloride-bicarbonate and the $\mathrm{pH}$ values are 7.2 to 7.9.

The geology of the Lena valley at Yakutsk consists of Late Quaternary alluvial deposits and Middle Jurassic rocks. The alluvium below the river channel is 6 to $18 \mathrm{~m}$ thick. It consists of fine- to medium-grained quartz and feldspar sands with quartz, chert, limestone and pyrite pebbles in the lower part. The underlying Middle Jurassic rocks include siltstones and quartz-feldspar and micaceous sandstones with frequent interbeds of clays. The hydraulic conductivity of the alluvium is 20-25 m/day and that of the Jurassic rocks is an order of magnitude less. 


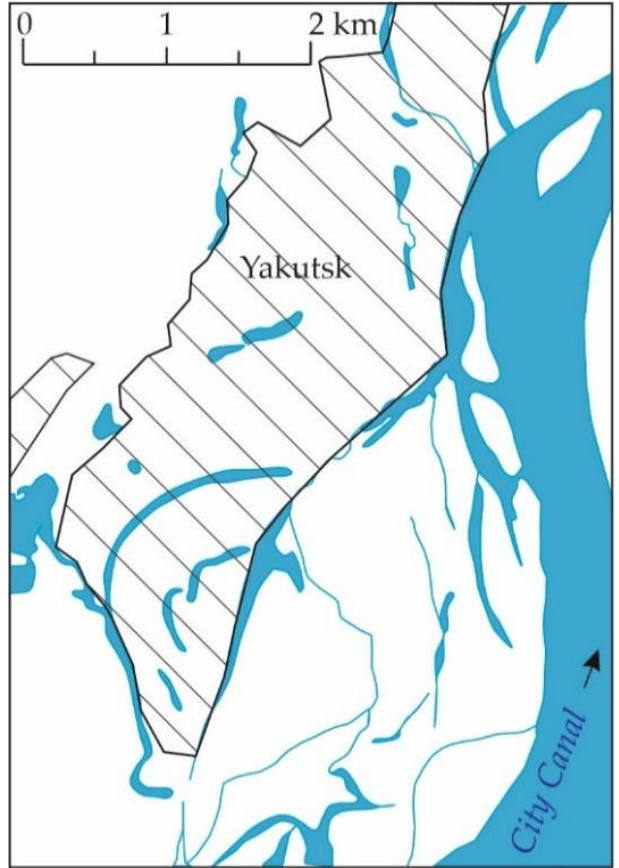

(a)

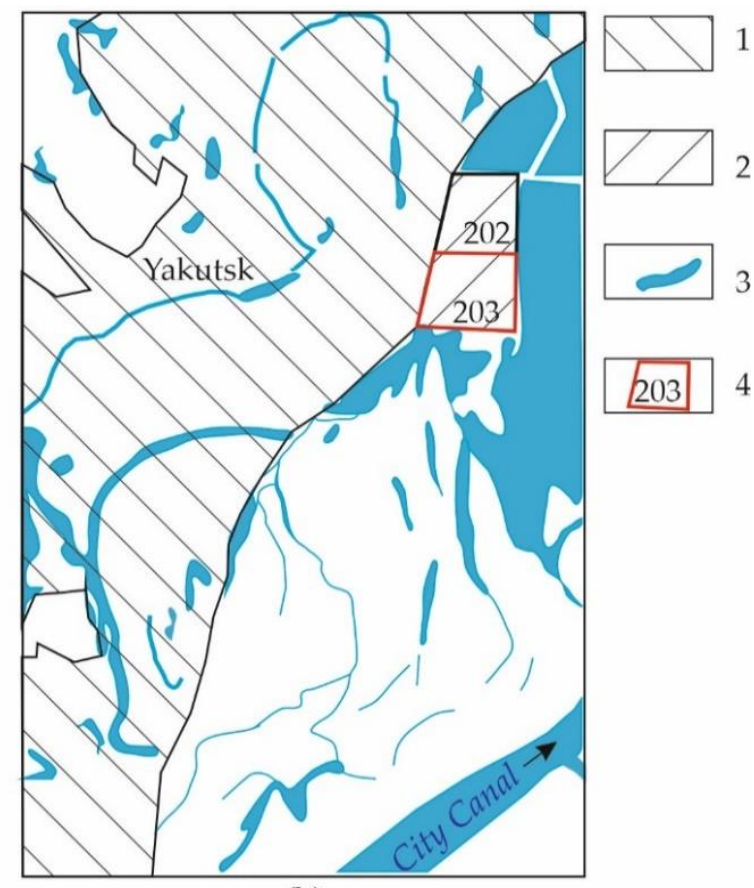

(b)

Figure 2. Layout maps of Yakutsk in 1946 (a) and 2019 (b). 1—city area; 2-reclamation area; 3-streams and lakes; 4 -study area and number district.

Suprapermafrost permeable taliks are present in the riverbed and floodplain (here and below the talik classes and types are given according to the N.N. Romanovsky's classification [36]). Below the channels with continuous flow, unfrozen water-bearing zones extend to depths of 40-60 $\mathrm{m}$ [37]. Within the floodplain, aquifers under the channels that cease flowing and freeze up in winter, as well as beneath the oxbow lakes are 10-12 $\mathrm{m}$ or less. The suprapermafrost groundwaters are confined below by permafrost. Drilling by Yakutskgeologia Co. on Khatystakh Island in the Lena valley near Yakutsk determined the base of permafrost to lie at $320 \mathrm{~m}$.

The chemical composition and solute contents in the sub-river groundwater vary with depth [35,37]. The dissolved-solids concentration in the Quaternary deposits increases from 0.38 to $0.84 \mathrm{~g} / \mathrm{L}, \mathrm{pH}$ varies from 6.7 to 7.9. The water type varies on an annual cycle depending on the chemistry of recharging river water. The water chemistry of the Middle Jurassic rocks is affected by relatively slow groundwater circulation, as evidenced by the high mineralization $(0.8-1.3 \mathrm{~g} / \mathrm{L})$ and alkalinity $(\mathrm{pH} 8.0-8.3)$ and the prevalence of sodium over other cations.

The Lena floodplain has a flat topography with elevations ranging between 85 and $89 \mathrm{~m}$. Prior to the reclamation of the land for Districts 202 and 203, the site had two large, 100-120 m wide oxbow lakes elongated in the direction of river flow (Figure 3). Relief between the bottom of the lakes and the intervening bar was $2.5-4.0 \mathrm{~m}$. The area was flooded annually during the spring and summer high flows. Closed water-bearing taliks, up to 7-15 $\mathrm{m}$ in thickness, were identified beneath the lakes in fine and medium-grained sands. The groundwater chemistry of the sub-lake taliks was generally similar to the sub-river taliks. The oxbow lakes were later buried by a 10 to $15 \mathrm{~m}$ fill.

The near-surface material between the lakes is composed of the floodplain facies consisting of silty sand and silt with inclusions of plant detritus and peat. These fine soils are less permeable than the sands beneath the oxbow lakes. Prior to the development, the depth of seasonal thaw under natural conditions was 1.5 to $3.0 \mathrm{~m}$ and ground temperatures at the depth of zero annual amplitude (10-12 m) ranged from minus $0.3-0.5^{\circ} \mathrm{C}$ to minus $0.8-1.2^{\circ} \mathrm{C}$. The placement of dredged fill for District 202 resulted in the lowering of the permafrost table in the bar areas due to the high-temperature slurry and the formation of water-bearing taliks, 3-5 $\mathrm{m}$ in thickness, below the 6-8 $\mathrm{m}$ fill [20]. 


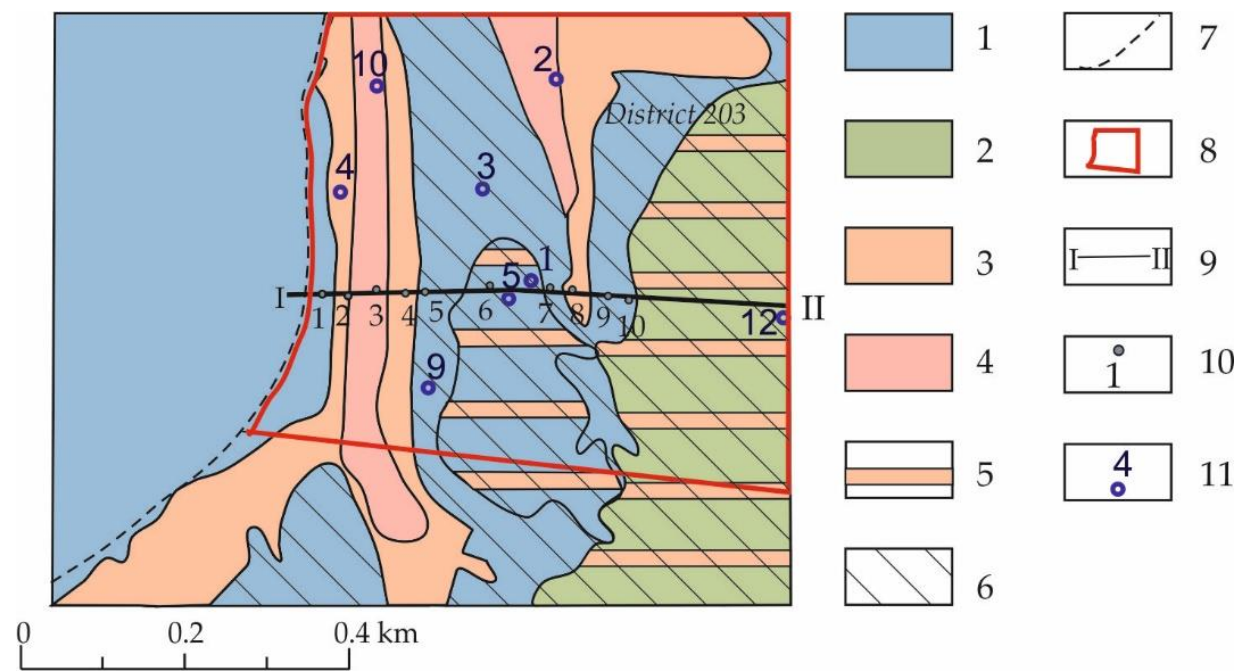

Figure 3. A sketch map showing permafrost conditions in the floodplain during hydraulic fill placement (compiled by Reference [15]): 1-vertically continuous permafrost (the active layer reaches the permafrost table); 2 -vertically discontinuous permafrost (the permafrost table lies deeper than the base of the active layer with a residual thaw layer of 1.0-1.2 m); 3-4-taliks confined to lake basins: 3-thickness <10 m; 4-thickness 10-15 m; 5-subordinate distribution of individual taliks $<10 \mathrm{~m}$ thick; 6-buried bars; 7-the boundary between the floodplain and the low terrace of the Lena River; 8-floodplain area planned for District 203 development; 9-line of geotechnical and hydrogeological boreholes; 10—geotechnical borehole and its ID; 11—hydrogeological borehole and its ID.

The reclaimed land created in the 1980s acted as a barrier to water flow, facilitating longer flooding of the adjacent floodplain areas during high flows. As a result, seasonal thaw depths in the area of future District 203 increased before the start of hydraulic filling [15]. Thin (up to 1.5-3.0 m) water-saturated soil layers locally persisted through the winter. The subsequent placement of the sand fill was accompanied by further thawing of the natural soils and widespread development of technogenic suprapermafrost water-bearing taliks. The upper part of the made ground drained under unconfined flow conditions.

\section{Results}

\subsection{Permafrost Conditions}

The fill in the District 203 area varies in thickness from 5.8 to $15.2 \mathrm{~m}$ (Figure 4). Seasonal ground freezing begins in mid-October when the mean daily air temperature falls below $0{ }^{\circ} \mathrm{C}$ (Figure 5). The maximum penetration depth of the zero isotherm is 3.8-5.0 $\mathrm{m}$ in May-June. Complete thawing of the frozen layer occurs in July-August. The mean ground temperature at the base of the seasonally freezing layer is $0.5-0.8^{\circ} \mathrm{C}$. The temperature in the depth range of aquifer occurrence is $0.6-1.0^{\circ} \mathrm{C}$.

Data from drilling investigations conducted between 2013 and 2019 indicate that the permafrost table lies at depths of 9.8-14.8 $\mathrm{m}$ in the areas of buried bars (see Figure 4). This is 2-3 $\mathrm{m}$ lower compared to the position in 1990 before the systematic filling operations were begun. Where the fill overlies the former oxbow lakes, the thickness of unfrozen ground is 16-20 or more. Sands in the aeration zone are dry, with volumetric water contents as low as 3-6\% within the upper 6-8 m. Soil moisture contents increase to $17-26 \%$ in the zone of seasonal groundwater level fluctuations. 


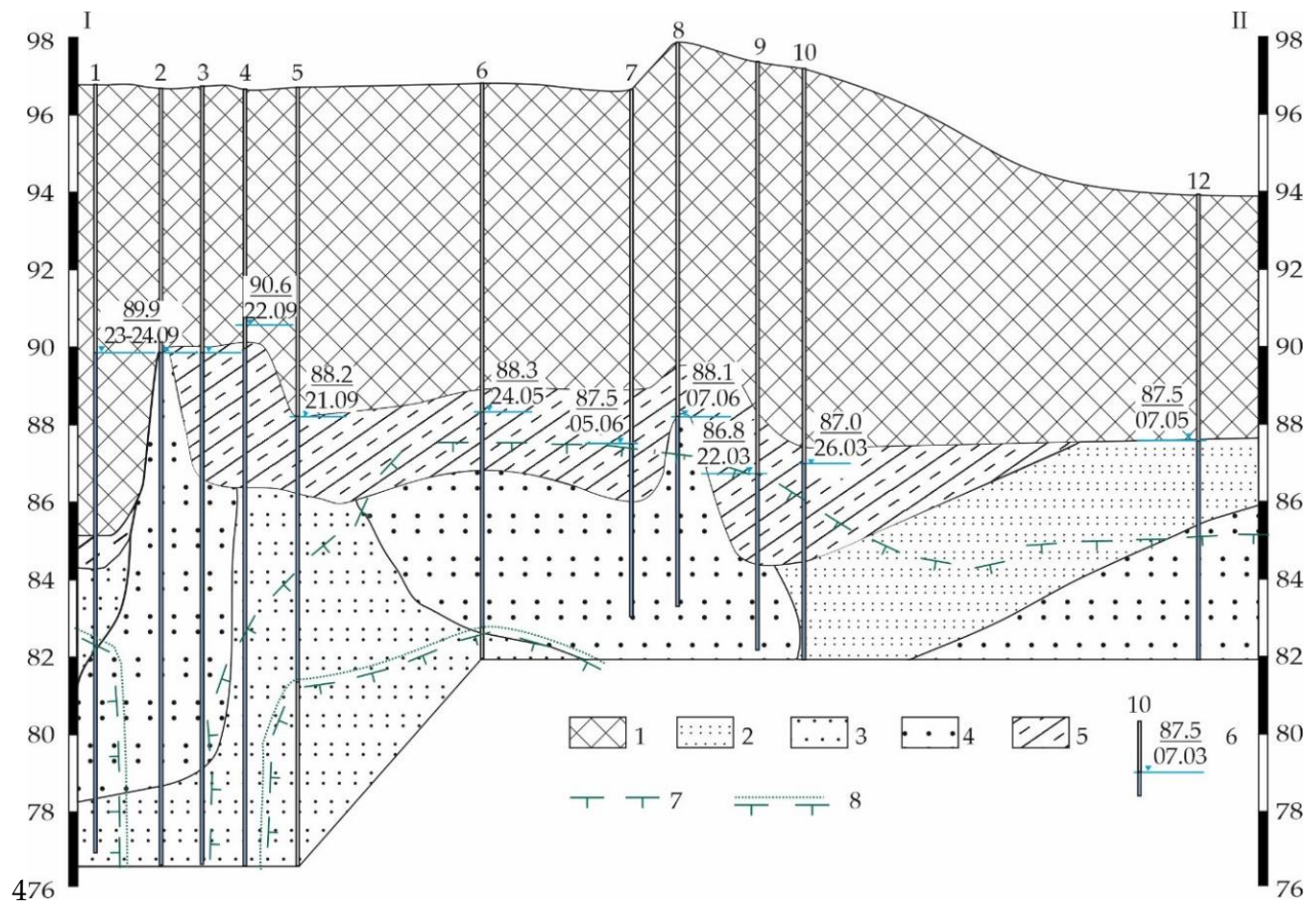

Figure 4. Cross-section along line I-II showing groundwater and permafrost levels (compiled by M.V. Danzanova from boring logs by YakutTISIZ Co. (1990) and Burstroy Ltd. (2016). 1-5-Soil lithology: 1-made ground (medium sand), 2-5-alluvial deposits: 2-silty sand; 3-fine sand; 4-medium sand; 5-sandy and clayey silts; 6-borehole with borehole no. (top), suprapermafrost groundwater level in 2016, m a.s.l. (numerator) and measurement date (denominator); 7-permafrost table in 1990; 8-permafrost table in 2016.

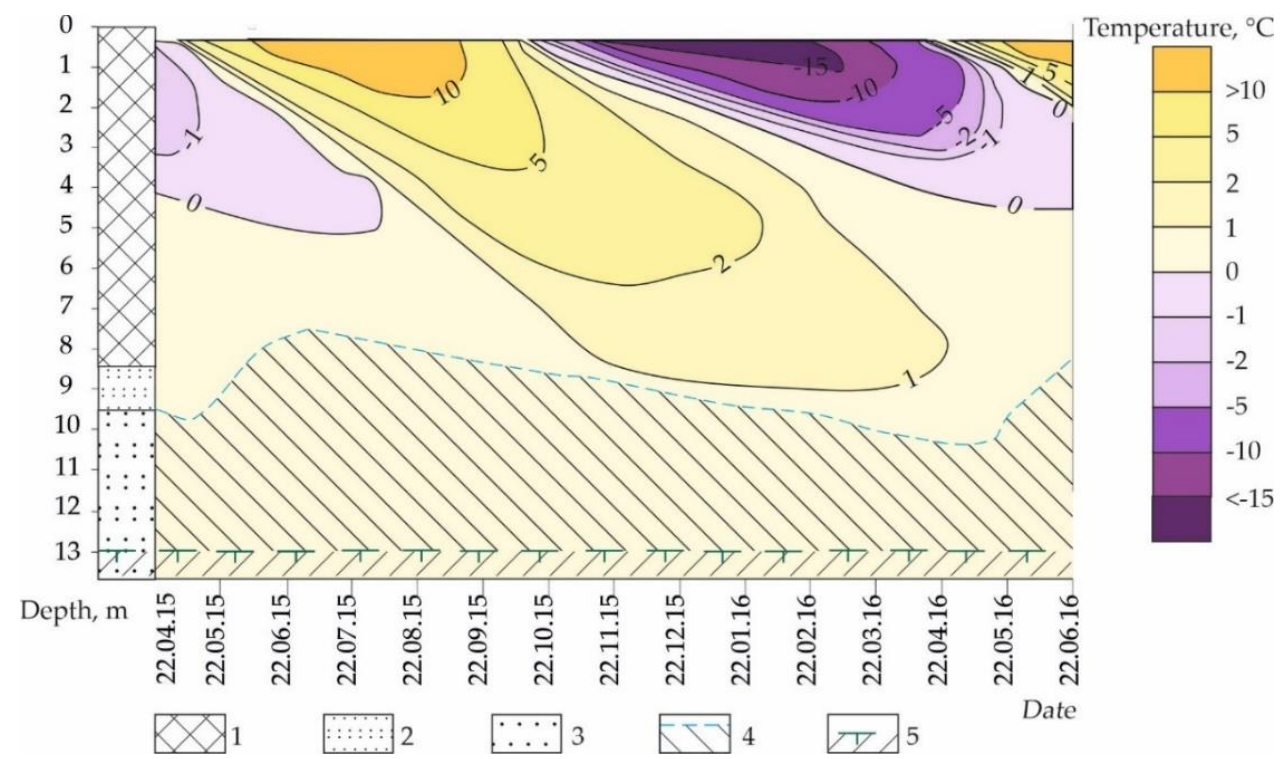

Figure 5. Variation in ground temperature and aquifer thickness on an annual basis (buried bar, borehole No 3). 1-3—soil lithology: 1—made ground (medium sand), 2-3—alluvial deposits: 2—silty sand; 3-fine sand; 4-aquifer; 5-permafrost table.

\subsection{Groundwater Levels}

Suprapermafrost groundwater occurs throughout the entire area. It was encountered by borings below depths of $6.4 \mathrm{~m}$ to $13 \mathrm{~m}$. The groundwater is generally unconfined, except where impervious 
soil layers locally create a head of $0.3-0.5 \mathrm{~m}$. The thickness of the saturated layer varies from $0.5-6.0 \mathrm{~m}$ in the buried bar areas to $12 \mathrm{~m}$ or more in the former locations of oxbow lakes, depending on the position of the confining permafrost (see Figure 4).

The free groundwater surface exhibits seasonal fluctuations (Figure 6). The minimum levels are observed in March-early May when the Lena River is in its winter low-flow regime. During this period, the water level in the river is 3-4 $\mathrm{m}$ lower than in the suprapermafrost talik in the fill land. In May, the river level rises rapidly with the arrival of the first flood wave. The river and groundwater levels equalize for 7-17 days. This is followed by increased recharge to the aquifer from the river due to the backwater effect. As the flood levels recede, groundwater levels in the buried taliks slowly fall during late June-early July.

Once the flood levels of the Lena River begin to subside, the water edge moves $\sim 3 \mathrm{~km}$ from the fill mass and the hydraulic gradient between the floodplain groundwater and the river decreases. This leads to slow drainage from the fill mass which continues until the next flood event.

The annual range of suprapermafrost groundwater level fluctuations which characterizes the magnitude of recharge to the aquifer was 2.4 to $3.2 \mathrm{~m}$ and 1.4 to $2.0 \mathrm{~m}$ in 2015-2016 and 2019, respectively. The smaller range in 2019 was likely due to the lower river levels that year (see Figure 6).

Precipitation accounts for a minor contribution to aquifer recharge because of its low amount (see Table 1 and Figure 6) and high evaporative loss. This is evidenced by the lack of groundwater level response to rain events.
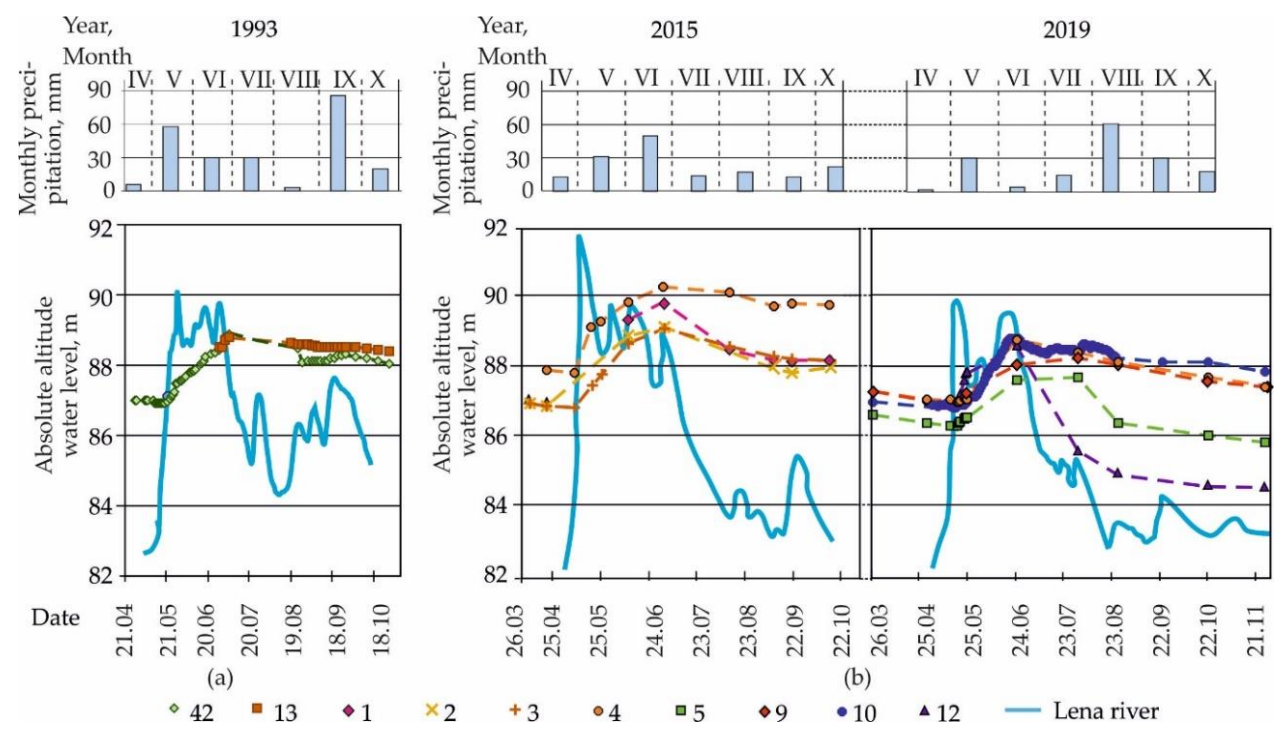

Figure 6. Variations in precipitation, Lena River water level, and groundwater level for selected years: (a) District 202 (based on data obtained by YakutPNIIS), and (b) District 203 (symbol numbers indicate borehole number).

\subsection{Chemistry of Surface and Subsurface Waters}

Groundwater samples from the land fill area have similar chemistry to the sub-river talik and the river water in winter (Figure 7). The water type is mixed-cation chloride-bicarbonate. Water mineralization in the aquifer varies with depth: the upper layers have lower salinity, while the lower layers have higher dissolved-solids concentrations with no change in water type. The dissolved-solids content also varies throughout the year, with maximum values $(0.6-0.8 \mathrm{~g} / \mathrm{L})$ in March-May (Table 2). In summer, groundwater mineralization decreases to $0.4-0.5 \mathrm{~g} / \mathrm{L}$ because of the inflow of ultra-fresh (mineralization $0.06-0.1 \mathrm{~g} / \mathrm{L}$ ) water from the Lena River. 


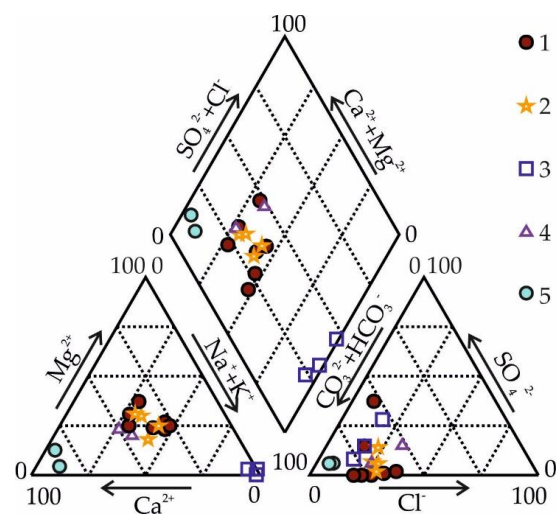

Figure 7. Chemical composition of natural waters in the study area (Piper diagram): 1-3 groundwater in suprapermafrost taliks: 1-taliks induced by fill placement; 2-taliks in Quaternary deposits beneath the Lena River; 3-taliks in Jurassic rocks beneath the Lena River; 4-Lena River water in winter; 5-precipitation.

Table 2. Chemistry of surface and subsurface waters in the study area in 2015-2016.

\begin{tabular}{|c|c|c|c|c|c|c|c|c|c|c|}
\hline \multirow{2}{*}{ Date } & \multirow{2}{*}{$\mathrm{pH}$} & \multirow{2}{*}{ Unit } & \multicolumn{4}{|c|}{ Cations } & \multicolumn{3}{|c|}{ Anions } & \multirow{2}{*}{ Minerali-Zation } \\
\hline & & & $\mathrm{Ca}^{2+}$ & $\mathrm{Mg}^{2+}$ & $\mathrm{Na}^{+}$ & $\mathrm{K}^{+}$ & $\mathrm{HCO}_{3}^{-}$ & $\mathrm{SO}_{4}{ }^{2-}$ & $\mathrm{Cl}^{-}$ & \\
\hline 1 & 2 & 3 & 4 & 5 & 6 & 7 & 8 & 9 & 10 & 11 \\
\hline \multicolumn{11}{|c|}{ Borehole No 3 (aquifer is in the depth range between 8.0 and $13.5 \mathrm{~m}$ ) } \\
\hline \multirow{2}{*}{21.04 .15} & \multirow{2}{*}{6.5} & $\mathrm{mg} / \mathrm{L}$ & 61.3 & 25.6 & 46.0 & 5.0 & 268.7 & 76.6 & 59.1 & 411.9 \\
\hline & & Mg-equiv/L & 3.06 & 2.11 & 2.00 & 0.13 & 4.40 & 1.59 & 1.67 & \\
\hline \multirow[b]{2}{*}{19.05 .15} & \multirow[b]{2}{*}{6.5} & $\mathrm{mg} / \mathrm{L}$ & 58.6 & 30.2 & 74.0 & 13.0 & 422.4 & 10.0 & 101.6 & 508.1 \\
\hline & & Mg-equiv/L & 2.92 & 2.48 & 3.22 & 0.33 & 6.92 & 0.21 & 2.87 & \\
\hline \multirow[b]{2}{*}{30.05 .15} & \multirow[b]{2}{*}{6.6} & $\mathrm{mg} / \mathrm{L}$ & 54.2 & 30.9 & 53.0 & 4.7 & 372.6 & 6.0 & 81.1 & 424.9 \\
\hline & & Mg-equiv/L & 2.71 & 2.54 & 2.30 & 0.12 & 6.11 & 0.12 & 2.29 & \\
\hline \multirow[b]{2}{*}{22.06 .15} & \multirow[b]{2}{*}{6.7} & $\mathrm{mg} / \mathrm{L}$ & 49.6 & 28.7 & 60.0 & 4.4 & 340.7 & 10.3 & 63.7 & 407.9 \\
\hline & & Mg-equiv/L & 2.473 & 2.36 & 2.61 & 0.11 & 5.584 & 0.2 & 1.797 & \\
\hline \multirow[b]{2}{*}{ 03.07.15 } & \multirow[b]{2}{*}{6.5} & $\mathrm{mg} / \mathrm{L}$ & 64.7 & 28.5 & 61.0 & 6.0 & 352.0 & 5.8 & 108.7 & 458.1 \\
\hline & & Mg-equiv/L & 3.23 & 2.35 & 2.65 & 0.15 & 5.77 & 0.12 & 3.07 & \\
\hline \multirow[b]{2}{*}{13.08 .15} & & $\mathrm{mg} / \mathrm{L}$ & 63.5 & 24.5 & 66.0 & 7.5 & 281.6 & 18.1 & 104.0 & 441.9 \\
\hline & 6.6 & Mg-equiv/L & 3.17 & 2.02 & 2.87 & 0.19 & 4.62 & 0.38 & 2.93 & \\
\hline & & $\mathrm{mg} / \mathrm{L}$ & 54.3 & 25.2 & 40.0 & 4.0 & 305.0 & 23.1 & 59.1 & 358.1 \\
\hline 21.09.15 & 6.7 & Mg-equiv/L & 2.71 & 2.07 & 1.74 & 0.10 & 5.00 & 0.48 & 1.67 & \\
\hline & & $\mathrm{mg} / \mathrm{L}$ & 62.6 & 29.4 & 44.0 & 4.0 & 328.5 & 30.9 & 68.0 & 407.6 \\
\hline 16.10.15 & 6.6 & Mg-equiv/L & 3.12 & 2.42 & 1.91 & 0.10 & 5.38 & 0.64 & 1.92 & \\
\hline & & $\mathrm{mg} / \mathrm{L}$ & 62.0 & 39.4 & 50.0 & 4.1 & 351.3 & 90.5 & 40.5 & 470.6 \\
\hline 15.01 .16 & 7.2 & Mg-equiv/L & 3.10 & 3.24 & 2.17 & 0.10 & 5.76 & 1.89 & 1.14 & \\
\hline & & $\mathrm{mg} / \mathrm{L}$ & 66.4 & 25.4 & 54.0 & 4.0 & 319.4 & 88.5 & 40.5 & 449.9 \\
\hline 25.02 .16 & 6.6 & Mg-equiv/L & 3.31 & 2.09 & 2.35 & 0.10 & 5.24 & 1.84 & 1.14 & \\
\hline & & $\mathrm{mg} / \mathrm{L}$ & 58.5 & 39.5 & 50.0 & 4.0 & 351.3 & 60.1 & 49.8 & 441.0 \\
\hline 30.03 .16 & 6.7 & Mg-equiv/L & 2.92 & 3.24 & 2.18 & 0.10 & 5.76 & 1.25 & 1.41 & \\
\hline & & Borehole & Jo 4 (aq & fer is in & depth & erval b & ween 8.0 a & $\mathrm{hd}>20 \mathrm{r}$ & & \\
\hline & & $\mathrm{mg} / \mathrm{L}$ & 55.9 & 30.2 & 103 & 27.0 & 460.6 & 5.8 & 118.2 & 577.5 \\
\hline 21.04 .15 & 6.9 & Mg-equiv/L & 2.79 & 2.48 & 4.48 & 0.69 & 7.55 & 0.12 & 3.33 & \\
\hline & & $\mathrm{mg} / \mathrm{L}$ & 47.7 & 25.2 & 125 & 33.0 & 470.2 & 4.1 & 126.5 & 606.5 \\
\hline 19.05 .15 & 7.1 & Mg-equiv/L & 2.38 & 2.07 & 5.44 & 0.84 & 7.71 & 0.09 & 3.57 & \\
\hline & & $\mathrm{mg} / \mathrm{L}$ & 56.9 & 37.1 & 117 & 21.0 & 574.9 & 5.1 & 107.2 & 641.3 \\
\hline 30.05 .15 & 6.9 & Mg-equiv/L & 2.84 & 3.05 & 5.09 & 0.54 & 9.42 & 0.11 & 3.02 & \\
\hline & & $\mathrm{mg} / \mathrm{L}$ & 56.6 & 35.1 & 110 & 21.0 & 500.4 & 0.8 & 115.9 & 596.0 \\
\hline 22.06 .15 & 6.9 & Mg-equiv/L & 2.82 & 2.89 & 4.78 & 0.54 & 8.20 & 0.02 & 3.27 & \\
\hline & & $\mathrm{mg} / \mathrm{L}$ & 51.1 & 31.0 & 97.0 & 23.0 & 469.3 & 1.6 & 99.9 & 545.6 \\
\hline 03.07.15 & 6.9 & Mg-equiv/L & 2.55 & 2.55 & 4.22 & 0.59 & 7.69 & 0.03 & 2.82 & \\
\hline & & $\mathrm{mg} / \mathrm{L}$ & 64.6 & 23.1 & 91.0 & 21.0 & 422.4 & 1.8 & 115.8 & 536.5 \\
\hline 13.08 .15 & 6.9 & Mg-equiv/L & 3.23 & 1.90 & 3.96 & 0.54 & 6.92 & 0.04 & 3.27 & \\
\hline & & $\mathrm{mg} / \mathrm{L}$ & 55.4 & 37.1 & 80.0 & 15.0 & 459.9 & 11.0 & 94.6 & 336.1 \\
\hline 21.09 .15 & 6.7 & Mg-equiv/L & 2.76 & 3.05 & 3.48 & 0.38 & 7.54 & 0.23 & 2.67 & \\
\hline & & $\mathrm{mg} / \mathrm{L}$ & 63.5 & 36.8 & 82.0 & 17.0 & 486.9 & 1.9 & 94.6 & 545.4 \\
\hline 16.10 .15 & 6.7 & Mg-equiv/L & 3.17 & 3.02 & 3.57 & 0.43 & 7.98 & 0.04 & 2.67 & \\
\hline & & $\mathrm{mg} / \mathrm{L}$ & 65.8 & 40.6 & 100 & 22.0 & 574.9 & 5.5 & 69.5 & 614.1 \\
\hline 14.12 .15 & 6.8 & Mg-equiv/L & 3.28 & 3.34 & 4.35 & 0.56 & 9.42 & 0.11 & 1.96 & \\
\hline & & $\mathrm{mg} / \mathrm{L}$ & 73.9 & 46.2 & 120 & 23.0 & 638.8 & 4.9 & 115.9 & 713.7 \\
\hline 15.01 .16 & 7.0 & Mg-equiv/L & 3.69 & 3.80 & 5.22 & 0.59 & 10.47 & 0.10 & 3.27 & \\
\hline & & $\mathrm{mg} / \mathrm{L}$ & 57.7 & 40.3 & 110 & 22.0 & 532.3 & 1.2 & 115.9 & 631.1 \\
\hline 25.02 .16 & 7.0 & Mg-equiv/L & 2.88 & 3.31 & 4.78 & 0.56 & 8.73 & 0.03 & 3.27 & \\
\hline & & $\mathrm{mg} / \mathrm{L}$ & 71.6 & 33.6 & 102 & 21.0 & 517.4 & 1.1 & 115.9 & 610.5 \\
\hline 30.03 .16 & 7.0 & Mg-equiv/L & 3.57 & 2.76 & 4.44 & 0.54 & 8.48 & 0.02 & 3.27 & \\
\hline
\end{tabular}


Table 2. Cont.

\begin{tabular}{|c|c|c|c|c|c|c|c|c|c|c|}
\hline \multirow{2}{*}{ Date } & \multirow{2}{*}{$\mathrm{pH}$} & \multirow{2}{*}{ Unit } & \multicolumn{4}{|c|}{ Cations } & \multicolumn{3}{|c|}{ Anions } & \multirow{2}{*}{ Minerali-Zation } \\
\hline & & & $\mathrm{Ca}^{2+}$ & $\mathrm{Mg}^{2+}$ & $\mathrm{Na}^{+}$ & $\mathrm{K}^{+}$ & $\mathrm{HCO}_{3}{ }^{-}$ & $\mathrm{SO}_{4}{ }^{2-}$ & $\mathrm{Cl}^{-}$ & \\
\hline 1 & 2 & 3 & 4 & 5 & 6 & 7 & 8 & 9 & 10 & 11 \\
\hline \multicolumn{11}{|c|}{ The Lena River } \\
\hline \multirow[t]{2}{*}{25.03 .15} & 7.0 & $\mathrm{mg} / \mathrm{L}$ & 31.2 & 24.1 & 78 & 1.5 & 129.8 & 65.9 & 140.9 & 407.7 \\
\hline & & Mg-equiv/L & 1.56 & 1.98 & 3.4 & 0.04 & 2.13 & 1.37 & 3.97 & \\
\hline \multirow[t]{2}{*}{31.05 .15} & 6.9 & $\mathrm{mg} / \mathrm{L}$ & 13.2 & 3.3 & 7.5 & 0.7 & 42.6 & 9.9 & 11.6 & 67.9 \\
\hline & & Mg-equiv/L & 0.66 & 0.27 & 0.3 & 0.02 & 0.70 & 0.21 & 0.33 & \\
\hline \multirow[t]{2}{*}{25.06 .15} & 7.0 & $\mathrm{mg} / \mathrm{L}$ & 12.4 & 4.7 & 10 & 0.9 & 46.3 & 9.9 & 14.3 & 76.6 \\
\hline & & Mg-equiv/L & 0.62 & 0.39 & 0.4 & 0.02 & 0.76 & 0.21 & 0.40 & \\
\hline \multirow[t]{2}{*}{02.07 .15} & 6.3 & $\mathrm{mg} / \mathrm{L}$ & 13.5 & 4.0 & 10 & 1.4 & 58.4 & 11.5 & 17.0 & 89.3 \\
\hline & & Mg-equiv/L & 0.67 & 0.33 & 0.4 & 0.04 & 0.96 & 0.24 & 0.48 & \\
\hline \multirow[t]{2}{*}{21.10 .15} & 7.2 & $\mathrm{mg} / \mathrm{L}$ & 26.5 & 9.9 & 23 & 0.8 & 89.2 & 26.0 & 47.3 & 178.4 \\
\hline & & Mg-equiv/L & 1.32 & 0.82 & 1.0 & 0.02 & 1.46 & 0.54 & 1.33 & \\
\hline \multirow[t]{2}{*}{27.11 .15} & 7.3 & $\mathrm{mg} / \mathrm{L}$ & 42.0 & 12.7 & 38 & 1.5 & 152.6 & 33.0 & 63.8 & 267.8 \\
\hline & & Mg-equiv/L & 2.09 & 1.05 & 1.6 & 0.04 & 2.50 & 0.69 & 1.80 & \\
\hline \multirow[t]{2}{*}{23.12 .15} & 7.2 & $\mathrm{mg} / \mathrm{L}$ & 46.6 & 17.0 & 39 & 1.3 & 190.2 & 30.0 & 61.2 & 290.3 \\
\hline & & Mg-equiv/L & 2.33 & 1.40 & 1.7 & 0.03 & 3.12 & 0.62 & 1.73 & \\
\hline \multirow[t]{2}{*}{28.01 .16} & 7.1 & $\mathrm{mg} / \mathrm{L}$ & 44.7 & 11.3 & 38 & 1.4 & 156.4 & 36.0 & 58.2 & 268.9 \\
\hline & & Mg-equiv/L & 2.23 & 0.93 & 1.6 & 0.04 & 2.56 & 0.75 & 1.64 & \\
\hline
\end{tabular}

\section{Discussion}

\subsection{The Reasons for Talik Preservation in the Reclaimed Floodplain}

Geothermal observations show that negative air temperatures do not penetrate deeper than the thickness of fill mass and do not reach the suprapermafrost groundwater table. Taliks retain in sandy deposits due to two probable reasons. The first is the physical properties of the fill mass itself. In winter soils in the upper part of the section practically do not contain moisture. At a moisture content of frozen sands of about $5 \%$, their thermal conductivity does not exceed $0.94-1.25 \mathrm{~W} /(\mathrm{m} \cdot \mathrm{K})$ [38]. The low thermal conductivity of dry sands prevents freezing from the surface. There were no special observations of water and ice content dynamics of hydraulic fill during the year. However, it can be assumed that in summer it is higher than in winter. This assumption is confirmed by the works by V.V. Shepelev and A.V. Boytsov [27,39]. They measured underground condensation in Central Yakutia and found that condensation processes occur most intensively in aeolian and alluvial medium-grained sands. The maximum increase in soil moisture is observed during relatively low summer air temperatures-in June, at the end of August and in September. In these months, the average daily condensate rate reaches $0.4 \mathrm{~mm} /$ day. The moisture accumulates between 0.4 and $1.5 \mathrm{~m}$ depth. Similar condensation processes probably occur in the fill mass in the studied area. Intra-ground condensation is accompanied by the thermal energy release $(2.5 \mathrm{MJ} / \mathrm{kg})$. In the permafrost environment, the warming effect of intra-ground condensation often exceeds the convective heating by precipitation infiltration [40]. In addition, a water content increase in thawed sand (up to field capacity) leads to a sharp rise in thermal conductivity [41]. Thus, a change in the thermal conductivity of sand in frozen and thawed conditions, together with the processes of intra-ground condensation, could contribute to more intensive soil thawing in the vadose zone than freezing, and the preservation of subaerial taliks in the fill mass.

As reported by many researchers, the increase in mean annual air temperature observed in central Yakutia since the 1980s is due primarily to shorter winter seasons and warmer winter temperatures [42-44]. It is unlikely in the near decades that the active layer will be deep enough to reach the permafrost.

Another reason why taliks do not freeze from below in the reclaimed floodplain is the active exchange of suprapermafrost groundwater with surface water. The reclaimed massif was developed in the area of the Lena river channel reshaping. The Lena River flowed through studied area 60-80 years ago. Despite the river channel migration channel and floodplain suprapermafrost, taliks have been preserved until the present. Water-bearing taliks within the area of the fill mass and in the adjacent territory was confirmed by drilling performed in the 1970s and in 2013-2019 [15,21]. 
The synchronism of the seasonal variability of chemical composition and water level in hydrogeological wells and Lena River confirms the hydraulic connection of groundwater with the river. Water exchange occurs by the filtration of river water along the contour of the fill mass and the movement of groundwater through a network of floodplain taliks. The direction of the filtration flow in taliks is controlled by fluctuations in the river water level. The annual amplitudes of groundwater levels in wells are less than in river water. This is probably due to the loss of flow energy while groundwater movement within the soil mass, and local heterogeneities of water-bearing rocks.

It is known that groundwater movement causes the occurrence of convective flows and the redistribution of heat, both laterally and vertically, in the aquifer [36]. Previous thermal analyses for the reclaimed land in Yakutsk assumed the absence of continuous groundwater flow at the bottom of the fill and considered only the soil thermal properties $[15,20]$. The modeling results predicted that the permafrost table would gradually rise and merge with the active layer. Currently, however, the unfrozen zone persists between the active layer and permafrost. The observed hydrogeological data suggest that the presence of talik zones which are indirectly connected with the Lena River via the sub-channel talik has an important, and as yet not fully understood, influence on the subgrade thermal regime.

\subsection{Soil Saturation Mechanisms}

Two mechanisms are responsible for soil saturation during the flood period. The first mechanism is the lateral seepage of river water into the fill mass across its perimeter. This is evidenced by distinct seasonal water-level changes in borehole \#12 located $46 \mathrm{~m}$ from the current floodplain in the buried bar area. By analogy with the modeling results obtained earlier for District 202 and confirmed by field observations [20], it is inferred that the extent of groundwater flooding due to lateral flow at 2015 and 2019 flood levels in the Lena River is expected to be 110-140 m (Figure 8).

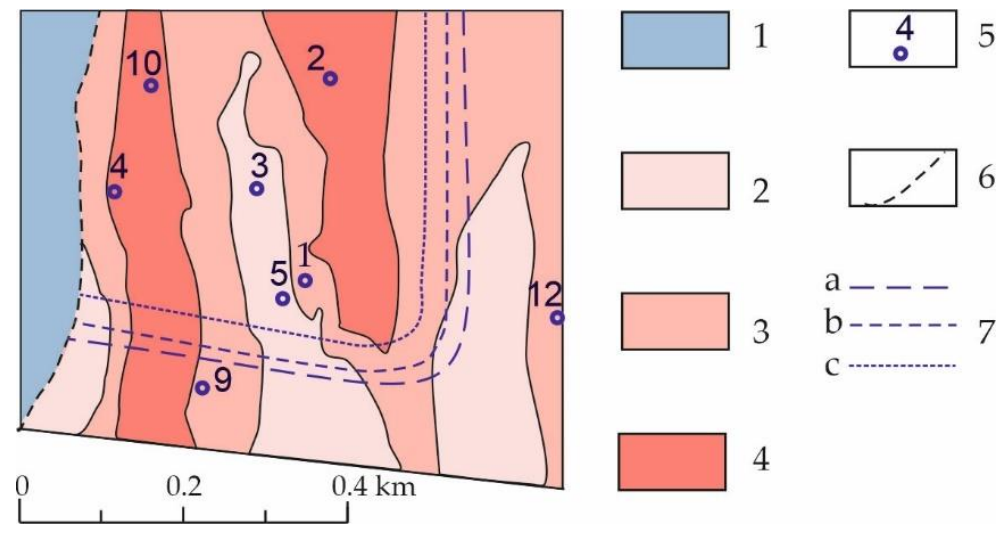

Figure 8. A sketch showing permafrost and groundwater conditions in the District 203 area in 2015-2019: 1-occurrence of suprapermafrost water of the active layer; 2-4-suprapermafrost taliks with unconfined groundwater: 2-talik thickness 10-15; 3-talik thickness 15-20 m; 4-talik thickness $>20 \mathrm{~m}$; 5-hydrogeological observation borehole and its ID; 6-the boundary between the floodplain and the low river terrace; 7 -limit of soil saturation due to lateral seepage for different probabilities (n) of Lena River levels: $\mathrm{a}-\mathrm{n}=50 \%(92.2 \mathrm{~m}) ; \mathrm{b}-\mathrm{n}=10 \%(94.7 \mathrm{~m}) ; \mathrm{c}-\mathrm{n}=1 \%(97.3 \mathrm{~m})$.

Rises in groundwater level during streamflow peaks were also seen in the boreholes at distances of 400-600 $\mathrm{m}$ from the floodplain. Previous studies in the adjacent area reported a similar pattern in 1992-1994 and partially attributed it to the effect of dredging operations and leaks from water utilities [15,20]. In 2015-2016 and 2019, in the absence of anthropogenic influences, the rise in groundwater level in May-late June which was observed across the entire District 203 area can only be explained by transmission of pressure from the river through the sub-channel talik hydraulically 
connected to the anthropogenic aquifer. The speed of hydrodynamic pulse propagation in the aquifer was estimated, using the station level records, to be approximately $4.6 \times 10^{3} \mathrm{~m}^{2} /$ day.

The river levels of $5 \%$ and $1 \%$ probability at Yakutsk, with account for historical extremes, are $94.7 \mathrm{~m}$ and $97.3 \mathrm{~m}$, respectively [31]. Then, considering the calculated hydraulic diffusivity, the groundwater table at the most distant point $(500 \mathrm{~m})$ from the river is predicted to rise by $4.5-6.0 \mathrm{~m}$ during extreme flood events, reaching levels of about $90-92 \mathrm{~m}$. These levels may be overestimated because groundwater flow below the fill has a complex nature and some part of inflow through the relict lakebed taliks will be redistributed into the permeable silty sands and silts comprising the bars.

Water chemical composition provides evidence of the close hydraulic relationship of suprapermafrost groundwater in the reclaimed floodplain and the Lena river through a network of floodplain taliks. Groundwater over an area of District 203 is chemically similar to the water of the alluvial Quaternary horizon, developed under the Lena River channel and in the floodplain. The TDS dynamics in groundwater under the fill is controlled by the seasonal variability of the chemical composition of the underflow and surface water. The observed shift between TDS extremes in the river and groundwater is associated with the time spent on the underground flow filtration in the alluvial deposits of the river valley.

The annual value of the natural (renewable) resources of suprapermafrost groundwater $\left(Q_{g} w r\right)$ in the territory of the District 203 in Yakutsk can be estimated by the formula:

$$
Q_{g w r}=Q / t
$$

where $Q$ is the water volume entering the fill, $t$ is the groundwater backwater time (average 36 days).

$$
Q=\Delta h \mu F
$$

where $\Delta h$ is the groundwater level rise during backwater (average $2.7 \mathrm{~m}$ ); $\mu$ is the deficiency of sand water saturation (0.15); $F$ is the area saturate $\left(0.34 \times 10^{3} \mathrm{~m}^{2}\right)$.

Based on available data, the underflow rate at the base of the fill is $\approx 3.8 \times 10^{3} \mathrm{~m}^{3} /$ day, and at extreme Lena River levels, it increases by 1.6-2.2 times.

Thus, the combination of factors affecting the ground thermal regime and hydrogeological conditions contributes to the preservation of suprapermafrost taliks in the reclaimed floodplain. Hence, foundation designs that utilize Principle II (permafrost thawing) appear more feasible for the reclaimed floodplain areas in the permafrost region.

\section{Conclusions}

Analysis of the hydrogeological data collected in 1994-1996 and 2015-2019 in the reclaimed floodplain areas of the Lena River indicates that the water-bearing taliks formed during the dredging and filling period have persisted to date. The groundwater regime beneath the fill mass is governed by the hydrological regime of the Lena River. Major changes in groundwater level and hydrochemistry occur during the spring flood. Two mechanisms lead to ground saturation during this period. One is lateral seepage from the Lena River into the fill mass. The zone of influence of rising river levels extends 150-170 $\mathrm{m}$ from the channel. The second mechanism is the transmission of hydraulic pressure from the stream through the sub-channel flow connected with the suprapermafrost aquifer. The influence of the latter mechanism is evident across the entire fill area. Pressure pulses propagating through the extant taliks can increase the groundwater levels by $4 \mathrm{~m}$ or more during extreme years, causing the risk of flooding to building basements.

The fill soils thus act as a water collector during the peak river flow period. During the periods of flood recession and low flows the suprapermafrost aquifer is discharged to the Lena River and underlying talik.

Continuous groundwater flow produces the thermal impact which prevents permafrost aggradation. Further monitoring will be aimed at quantifying the thermal effects of water-bearing 
taliks on the ground temperature regime considering the complex nature of groundwater movement beneath the fill, as well as the superposition of anthropogenic warming of the subgrade soils.

Understanding the hydraulic connection between the river and suprapermafrost groundwater is particularly important under the observed climatic variations which may increase the frequency of severe floods and hence the risk of inundation to building foundations.

The hydrological interactions identified must be taken into account in strategic planning of floodplain development in permafrost regions, as well as in assessing groundwater inundation risk from river floods in filled land.

Author Contributions: N.P. and V.O. conceived the idea of the study, carried out data analysis and wrote the first manuscript draft; N.P. supervised the research project and contributed to oversight of the data collection; M.D. and V.P. contributed critical conceptual review and manuscript revisions; all authors approved the final manuscript. All authors have read and agreed to the published version of the manuscript.

Funding: This study was partially supported by the Russian Foundation for Basic Research (research project no. 20-05-00670).

Conflicts of Interest: The funders had no role in the design of the study; in the collection, analyses, or interpretation of data; in the writing of the manuscript, or in the decision to publish the results.

\section{References}

1. Hoff, J.; Nooy van der Kolff, A. (Eds.) Hydraulic Fill Manual: For Dredging and Reclamation Works; CRC Press: London, UK, 2012; p. 672. [CrossRef]

2. Sengupta, D.; Chen, R.; Meadows, M.E.; Choi, Y.R.; Banerjee, A.; Zilong, X. Mapping Trajectories of Coastal Land Reclamation in Nine Deltaic Megacities using Google Earth Engine. Remote Sens. 2019, 11, 2621. [CrossRef]

3. Kaminskaya, V.I. The main features of designing and building the hydraulic-fill territories for the offshore passenger terminal in Saint Petersburg. Gornyi Informatsionno-Analiticheskii Bulleten 2009, 1, 444-451.

4. Zharkova, N.I.; Cherniichuk, G.A.; Zharkov, I.Y.; Galeev, R.K. Artificial soils in Kazan: Features of composition formation, structure and properties. Uchenye Zapiski Kazanskogo Universiteta 2013, 155, 130-143.

5. Preobrazhenskii, A.A.; Kanakov, G.V. The problems and prospects of construction in reclaimed floodplain in Nizhny Novgorod region. In Mezhvuzovskii Sbornik Statei Laureatov Konkursov, 12th ed.; Nizhny Novgorod State University of Architecture and Civil Engineering: Nizhny Novgorod, Russia, 2010; pp. 86-88.

6. Dimuhametov, M.S.; Dimuhametov, D.M. Physico-mechanical properties of the peaty soils of the Kama valley of Perm city and their changes as a result of loading action. Vestnik Permskogo Universiteta 2009, 11, 94-107.

7. Chistobaev, A.I.; Visleneva, O.A. Is there land shortage for urban development in Russia? Regionalnaya Ekologiya 2013, 1-2, 46-50.

8. Kaminskaya, V.I. Design Optimization of Solutions and Technologies for the Construction of Hydraulic-Fill Structures; Stroyizdat North-West: Saint Petersburg, Russia, 2011; p. 163.

9. Kovrov, O.S.; Prychyna, K.S. Slope stability assessment of hydraulic-fill soil dams and fill-up embankments. Naukovyi Visnyk Natsionalnoho Hirnychoho Universytetu 2017, 6, 115-123.

10. Tezcan, S.O.; Bhatia, S.K.; Fiegle, S. Seismic Stability and Rehabilitation Analysis of a Hydraulic Fill Dam. In Proceedings of the International Conferences on Recent Advances in Geotechnical Earthquake Engineering and Soil Dynamics, San Diego, CA, USA, 26-31 March 2001; p. 29.

11. Ogorodnikova, E.N.; Nikolaeva, S.K. Geocological features of land reclaimed by hydraulic filling. In Proceedings Sergeevskie Chteniya. Engineering Geology and Environmental Geoscience. Fundamental Problems and Applied Task; RUDN Press: Moscow, Russia, 2016; Volume 18, pp. 331-335.

12. Kitze, F.F.; Simoni, O.W. An Earth Fill Dam on Permafrost, Hess Creek Dam, Livengood, Alaska; Technical Report No. 196; U.S. Army Cold Regions Research and Engineering Laboratory: Hanover, NH, USA, 1972; pp. 1-51.

13. Mitchell, D.E.; McRae, T.E. Densification of Submarine Hydraulic Fills. In Proceedings of the Offshore Technology Conference, Houston, TX, USA, 6-9 May 1985. [CrossRef]

14. Konovalov, P.A.; Kushnir, S.Y. Hydraulic Fill Ground as the Foundation of Structures; Nedra: Moscow, Russia, 1991; p. 256.

15. Roman, L.T.; Tsernant, A.A.; Poleshchuk, V.L.; Tseeva, A.N.; Levanov, N.I. Construction on Hydraulic Fills on Permafrost; Publishing House Economics, Construction, Transport: Moscow, Russia, 2008; p. 323. 
16. Zhang, R.V.; Kuzmin, G.P. Alluvial hydraulic engineering constructions in the permafrost area of Russia: Experience of construction, problems and possibilities of use of borehole hydroproduction. Nauka Obrazovanie 2015, 2, 63-69.

17. Recommendations for Engineering and Geological Surveys and Design of Buildings and Structures Foundations on Hydraulic-Fill Tterritories; NIIOSP: Moscow, Russia, 1985; p. 38.

18. Soil Bases and Foundations on Permafrost; SP 25.13330.2012; NIIOSP: Moscow, Russia, 2012; p. 236.

19. Poleschuk, V.L. Creation of building sites on permafrost by hydraulic filling. In Proceedings, Workshop on Productive Forces Development in the Yakut ASSR; Yakutsk Book Publishing House: Yakutsk, Russia, 1981; pp. 10-15.

20. Roman, L.T.; Poleschchuk, V.L.; Tseeva, A.N.; Ignatova, G.M.; Egorov, G.E. Securing reliability of building on silt soils in the permafrost zone (on the example of Yakutsk). Kriosfera Zemli 1998, 2, 72-81.

21. Shesternev, D.M.; Zhang, R.V.; Kuzmin, G.P.; Shepelev, V.V.; Pavlova, N.A.; Popenko, F.E. Industrial and residential construction on hydraulic fill in permafrost regions; problems and prospects. J. Eng. Heilongiiang Univ. 2014, 5, 100-109. [CrossRef]

22. Syromyatnikov, I.I.; Kunitsky, V.V. Features of the temperature regime of dredged sands in District 202. In Proceedings, VIII Russian Scientific and Practical Conference "Geology and Mineral. Resources of North.-East. Russia"; Melnikov Permafrost Institute SB RAS Press: Yakutsk, Russia, 2018; Volume 2, pp. 282-285.

23. Ogonerov, V.V.; Pavlova, N.A.; Danzanova, M.V. Hydrogeology of Reclaimed Floodplains in Permafrost Areas: A Case Study of Yakutsk. In Proceedings, International Youth Scientific Conference "Environmental Problems of Nature and Subsoil Use", 2nd ed.; Kurylenko, V.V., Ed.; St. Petersburg State University: St. Petersburg, Russia, 2019; Volume 19, pp. 264-268.

24. Spektor, V.V.; Bakulina, N.T.; Spektor, V.B. Landforms and age of alluvium in the Lena valley in "Yakutsky Razboi". Geomorfologiya 2008, 1, 87-94.

25. Balobaev, V.T.; Ivanova, L.D.; Nikitina, N.M.; Shepelev, V.V.; Lomovtseva, N.S.; Skutin, V.I. Ground Water in Central Yakutia and Its Prospective Use; SB RAS Press, Geo Branch: Novosibirsk, Russia, 2003; p. 137.

26. Syromyatnikov, I.I.; Fedorov, A.N.; Kunitsky, V.V.; Dorofeev, I.V. Permafrost rocks in Yakutsk. In Applied Ecological Problems in Yakutsk; Nauka: Novosibirsk, Russia, 2017; pp. 24-32.

27. Shepelev, V.V. Suprapermafrost Waters in the Cryolithozone; Academic Publishing House "Geo": Novosibirsk, Russia, 2011; p. 167.

28. Pavlova, N.A.; Danzanova, M.V.; Serikov, S.I. Assessment of anthropogenic effect on surface ponding and hydrochemical conditions in the city of Yakutsk. Geoekologiya 2014, 3, 207-214.

29. Bochever, F.M.; Garmonov, I.V.; Lebedev, A.V.; Shestkov, V.M. Fundamentals of Hydrogeological Analyses; Nedra: Moscow, Russia, 1969; p. 368.

30. Surface Water Resources in the USSR. Lena-Indigirka Basin; Gidrometeoizdat: Leningrad, Russia, 1972; Volume 17, p. 562.

31. Rozhdestvenskii, A.V.; Buzin, V.A.; Shalashina, T.L. Conditions of maximum water level formation of the Lena River near Yakutsk. Meteorol. Gigrologiya 2010, 10, 77-87.

32. Gautier, E.; Dépret, T.; Virmoux, C.; Grancher, D.; Brunstein, D.; Costard, F.; Fedorov, A.; Konstantinov, P. Going with the flow: Hydrologic response of middle Lena River (Siberia) to the climate variability and change. J. Hydrol. 2018, 557, 475-488. [CrossRef]

33. Chalov, R.S.; Zavadsky, A.S.; Ruleva, S.N.; Kirik, O.M.; Prokop'yev, V.P.; Androsov, I.M.; Sakharov, A.I. Morphology, deformations and temporary modifications of the Lena River channel and its influence on the Yakutsk economic infrastructure. Geomorfologiya 2016, 3, 22-35. [CrossRef]

34. Tananaev, N. Hydrological and sedimentary controls over fluvial thermal erosion, the Lena river, Central Yakutia. Geomorphology 2016, 253, 524-533. [CrossRef]

35. Anisimova, N.P.; Pavlova, N.A. Hydrogeochemical Studies of Permafrost in Central Yakutia; Academic Publishing House "Geo": Novosibirsk, Russia, 2014; p. 189.

36. Romanovsky, N.N. Groundwater in Permafrost; Moscow State University Press: Moscow, Russia, 1983 ; p. 231.

37. Anisimova, N.P.; Pavlova, N.A.; Stambovskaya, Y.V. Chemical composition of talik waters in the middle Lena River. Nauka Obrazovanie 2005, 4, 118-124.

38. Gavriliev, R.I. Thermal Properties of Rocks and Soil Cover in Permafrost; SB RAS Publishing House: Novosibirsk, Russia, 1998; p. 280. 
39. Boitsov, A.V.; Shepelev, V.V. Permafrost-hydrogeological conditions of the mass of eolian sands of Makhatta (Central Yakutia). In Hydrogeological Studies of the Cryolithozone; Melnikov Permafrost Institute SB RAS Press: Yakutsk, Russia, 1976; pp. 25-34.

40. Ershov, E.D. Ceneral Geocryology: Manual for High; Moscow University Press: Moscow, Russia, 2002 ; p. 682.

41. Garagulya, L.S.; Kudryavtsev, V.A.; Kondratieva, K.A. Fundamentals of Permafrost Forecast in Engineering and Geological Research; MSU Publishing House: Moscow, Russia, 1974; p. 432.

42. Skachkov, Y.B. Trends in extreme air temperatures in Yakutsk. Nauka Obrazovanie 2012, 2, $39-41$.

43. Varlamov, S.P.; Skryabin, P.N.; Skachkov, Y.B. Ground temperature monitoring in the Tuimaada valley. In Proceedings, Solutions to Key Development Problems in Yakutsk City: Theoretical Background; Sfera: Yakutsk, Russia, 2010; pp. 97-102.

44. Iijima, Y.; Park, H.; Suzuki, K.; Yabuki, H.; Ohata, T.; Fedorov, A.N.; Maximov, T.C. Abrupt Increases in Soil Temperatures Following Increased Precipitation in a Permafrost Region, Central Lena River Basin, Russia. Permafr. Periglac. Process. 2010, 2, 30-41. [CrossRef]

(C) 2020 by the authors. Licensee MDPI, Basel, Switzerland. This article is an open access article distributed under the terms and conditions of the Creative Commons Attribution (CC BY) license (http://creativecommons.org/licenses/by/4.0/). 